\title{
Concentration and size distribution of microbial aerosol in the historical objects in Kraków as a potential health risk and biodeterioration factor
}

\author{
Maria Chmiel · Iga Kral • Anna Lenart-Boroń $\mathbb{D}$
}

Received: 15 February 2019/Accepted: 12 October 2019/Published online: 23 October 2019

(C) The Author(s) 2019

\begin{abstract}
Historical facilities such as churches, crypts, libraries and museums are crucial for preserving cultural heritage but at the same time, they are frequently visited tourist objects and working environment. The aim of this study was to assess whether there are differences in the concentration and size distribution of bacterial and fungal aerosol in the mentioned groups of historical objects in Kraków, as well as to determine if there is tendency for seasonal fluctuations of bioaerosol concentrations, and what environmental parameters affect them most significantly. The concentrations of bacterial and fungal aerosol were measured in ten historical objectschurches, crypts, libraries and museums-using a sixstage Andersen impactor. Microbiological analyses were accompanied by measurements of particulate matter $\left(\mathrm{PM}_{10}, \mathrm{PM}_{4}, \mathrm{PM}_{2.5}\right.$ and $\left.\mathrm{PM}_{1}\right)$ and microclimatic parameters. The results showed that the studied objects differ in terms of bioaerosol levels, but the differences were not drastic and in terms of bacterial aerosol concentrations the objects can be arranged as follows: churches $>$ libraries $>$ museums $>$ crypts, while for fungal aerosol the order would be: churches $>$ museums $>$ crypts $>$ libraries. The concentrations of bioaerosol did not exceed the safety
\end{abstract}

M. Chmiel · I. Kral · A. Lenart-Boroń ( $₫)$

Department of Microbiology and Biomonitoring,

University of Agriculture in Kraków, Mickiewicza Ave

24/28, 30-059 Kraków, Poland

e-mail: anna.lenart-boron@urk.edu.pl levels for human exposure, but the levels suggesting possible threat of biodeterioration and the presence of internal source of contamination were exceeded in nearly all sites. The share of respirable fraction of bioaerosol was high $(42.1-90.5 \%$ for bacteria and $80.7-94.7 \%$ for fungi). Bioaerosol concentration was most significantly associated with indoor temperature, and the impact of particulate matter was only moderate.

Keywords Bioaerosol · Historical objects · Indoor air quality $\cdot$ Particulate matter

\section{Introduction}

Kraków is among the most frequently visited tourist cities in Poland. Two of its districts (Old Town and Kazimierz) are included in the UNESCO World Heritage List. There are numerous historical objects in Kraków, among which there are museums, architectural and religious monuments (both Catholic and Jewish), as well as libraries and archives, constituting not only cultural and historical heritage, but also tourist attractions. At the same time, for several years Kraków has been struggling with the growing problem of air pollution and smog. The location of the city makes it one of the most polluted cities in the world. According to the local institutions, there are less than 
$50 \%$ of days during the year when the particulate matter concentration does not exceed the limit values. Some authors (e.g., Dong et al. 2016) indicate a positive correlation between the particulate matter concentration and the levels of airborne microorganisms. In general, bioaerosol presence in indoor environments can originate from outdoor air or from humans, e.g., building occupants or visitors, and can vary greatly depending on their activities (Aydogdu et al. 2010).

Historical objects, including churches, crypts, museums and libraries, are places that are crucial for preserving the cultural heritage. It was shown in previous studies that such premises are characterized by significant microbiological contamination (Skóra et al. 2012; Karbowska-Berent et al. 2011). In the historical objects, such as museums, churches, crypts or libraries, the main source of microorganisms is transporting on humans-employees and visitors or with outdoor air through doors and windows (Niesler et al. 2010). Also, environmental conditions (e.g., temperature and relative humidity $[\mathrm{RH}]$, or poor ventilation) in historical buildings are favorable for the growth and spreading of microorganisms (Valentin 2003). Therefore, bioaerosol-forming microorganisms in museum premises are among the most important risk factors for the health of museum employees and tourists, as well as can be among factors causing the biodeterioration of cultural heritage relics (Niesler et al. 2010). Another important factor affecting the importance of microorganisms in historical buildings is that many museum exhibits or their elements are made of organic materials, making them particularly vulnerable to the biodeterioration process (Niesler et al. 2010). Historical objects, mainly books, paper documents, paintings or wood sculptures, can be efficiently destroyed due to cellulolytic properties of some bacteria (e.g., Streptomyces spp.) and numerous fungi, among others from the genera of Alternaria, Aspergillus, Penicillium or Trichoderma. Lipolytic and proteolytic properties of bacterial and fungal strains are also important in the process of biodeterioration of historical objects, such as leather or parchment (Strzelczyk 2004).

Health threats in historical institutions are related to the inhalation of air that can be contaminated by microorganisms or by handling of mold-infested objects (Skóra et al. 2015). Wiszniewska et al. (2009) suggested that professional exposure to mold fungi may have a significant relation to the development of allergic reactions among museum workers. They reported the presence of allergic symptoms in as many as $85 \%$ of workers with $31 \%$ who reported developing symptoms during work with objects potentially contaminated with fungi. Also, exposure to bacterial aerosol can pose health threats- the most commonly occurring groups of bacteria in indoor air are Gram-positive rods and cocci, including various species of Staphylococcus, many of which have the potential to be opportunistic pathogens or to carry antibiotic resistance genes (Brągoszewska and Biedroń 2018; Brạgoszewska et al. 2016). It is widely known that contact with bioaerosols can cause a variety of infectious diseases and allergies and the probability of occurrence as well as the severity of the potential disease depends on a number of factors. These include the biological properties and chemical composition of bioaerosols, such as content of heavy metals in airborne particulate matter (Liu et al. 2015), but also the amount of inhaled microorganisms and their deposition in the respiratory tract are significant parameters (Braggoszewska and Pastuszka 2018). The site of deposition in the respiratory tract is directly associated with the aerodynamic diameter of particles, which can vary from approx. 0.02 to $100 \mu \mathrm{m}$. The size distribution of bioaerosols depends on the types of microorganisms, the age of spores, aggregation rates of spores and types of particles they are associated with (Nasir and Colbeck 2010). This results in the bioaerosols being divided into respirable and nonrespirable fractions. The size of the former ones is $<5 \mu \mathrm{m}$, and they pass beyond the larynx and deposit in the alveoli, causing more severe reactions than the non-respirable fractions of bioaerosols, which deposit in the upper respiratory tract and can rather cause only allergic symptoms (Brągoszewska et al. 2018). This shows the clear relationship between the presence of respirable fractions (RF) of bioaerosols and dust particles and their pathogenic potential and indicates that information on the total concentration of bioaerosols in various types of indoor environments is insufficient. Also, what is important is that numerous studies have been carried out in order to assess the quality of both indoor and outdoor air (Aydogdu et al. 2010; Brągoszewska et al. 2016; Brągoszewska and Biedroń 2018; Dong et al. 2016; Liu et al. 2015), but only few of them concern more detailed studies of bioaerosol in historical buildings such as museums, 
libraries, churches or crypts, mostly due to the limited or restricted access to such institutions.

Given the above, this study was conducted to give a preliminary view of the levels of bacterial and fungal aerosols, including their size distribution, in various groups of historical objects in Kraków. The specific aims were to determine (1) whether museums, libraries, churches and crypts differ in the concentrations of bioaerosols, (2) whether there is a trend of seasonal differences in the concentrations of biological aerosols and (3) to assess whether the environmental parameters, such as temperature, relative humidity and dust concentration, differ between these objects, and to what extent they affect the concentrations of bacterial and fungal aerosols.

\section{Materials and methods}

The study was conducted over a period of 1 year in ten historical objects, classified into four groupschurches, crypts, libraries and museums located in one of the most popular Polish tourist cities-Kraków. The site located on the Main Market Square was treated as an external background control. A brief description of the sampling sites along with basic environmental parameters is presented in Table 1 . The air samples were collected in four series, once per each season of the year (spring - 15th April, summer-20th August, autumn-3rd November, winter-30th January). The sampling dates were selected by taking into consideration the microclimatic parameters, such as temperature, humidity, precipitation and wind speed, and by excluding days with extreme weather conditions (such as heavy rainfall, unusually high or low temperature of air, strong wind), in order to conduct our analyses on dates representing the most typical weather conditions for each season. Temperature and relative humidity were measured using the Kestrel 4000 Weather Meter (Nielsen-Kellerman, USA). Dust concentration was measured using a DustTrak ${ }^{\mathrm{TM}}$ II Aerosol Monitor 8530 (TSI Inc., USA) laser photometer. The device allows to measure four fractions of dust: $\mathrm{PM}_{10}$ (i.e., dust particles not larger than $10 \mu \mathrm{m}$ ), $\mathrm{PM}_{4}, \mathrm{PM}_{2.5}$ and $\mathrm{PM}_{1}$ (dust particles with diameters of $4,2.5$ and $1 \mu \mathrm{m}$, respectively), using interchangeable heads. The sampling time for each dust fraction was $1 \mathrm{~min}$.
Collection of air samples was conducted using two six-stage Andersen cascade impactors (model WES710, Westech Instrument, UK), allowing to distinguish the following aerodynamic diameters of bioaerosol: $7 \mu \mathrm{m}$ (stage 1), 4.7-77 $\mu \mathrm{m}$ (stage 2), 3.3-4.7 $\mu \mathrm{m}$ (stage 3), 2.1-3.3 $7 \mu \mathrm{m}$ (stage 4), 1.1-2.1 $7 \mu \mathrm{m}$ (stage 5) and 0.65-1.1 $7 \mu \mathrm{m}$ (stage 6). The sampling time was $5 \mathrm{~min}$, which-providing the constant flow rate of $28.3 \mathrm{l} / \mathrm{min}$ — gives the volume of $141.5 \mathrm{l}$ of aspirated air. The air samplers were placed at the height of $1.5 \mathrm{~m}$ above the ground level to collect the air from the human breathing zone. The samples were collected two times per day (in the morning - between c.a. 6 and c.a. $8 \mathrm{AM}$, i.e., before the opening hours, and in the evening-between c.a. 8 and c.a. 10 PM, i.e., after closing of the examined objects; detailed data not shown) and the measurements were conducted in three replicates. With six impaction stages for each combined sample and two groups of microorganisms tested, 72 samples were collected per each season288 in total. The samples were collected one after another, and between each sampling, the impactors were disinfected by using cotton balls immersed in $70 \%$ ethanol. The following microbiological media were used: trypticase soy agar (Biocorp, Poland) and malt extract agar (Biocorp, Poland) for the isolation of bacteria and fungi, respectively. One of the impactors was used for the collection of bacteria and the second one for the collection of fungi. The plates with TSA were incubated at $37{ }^{\circ} \mathrm{C}$ for 1 day, then at $22{ }^{\circ} \mathrm{C}$ for next 3 days and at $4{ }^{\circ} \mathrm{C}$ for another 3 days, while the plates with MEA were incubated at $30{ }^{\circ} \mathrm{C}$ for 4 days, followed by incubation at $22{ }^{\circ} \mathrm{C}$ for another 4 days. After incubation, the colonies were counted and the results were expressed as the number of colonyforming units per $\mathrm{m}^{3}$ of air $\left(\mathrm{CFU} / \mathrm{m}^{3}\right)$. The results from three replications were used to calculate mean values, which are shown as final results in figures and tables The obtained results were compared with the guidelines of the Team of Experts in Biological Factors (pol.: ZECB) (Skowroń 2014) on the concentrations of airborne microorganisms in indoor air of museums, archives, libraries, conservation workshops, etc., which are: $5000 \mathrm{CFU} / \mathrm{m}^{3}$ for both bacteria and fungi-acceptable from the viewpoint of exposed people and $150 \mathrm{CFU} / \mathrm{m}^{3}$ which is the technical value of bioaerosol suggesting the presence of microbial contamination sources in the examined premises, harmful in terms of preservation of the stored objects. 


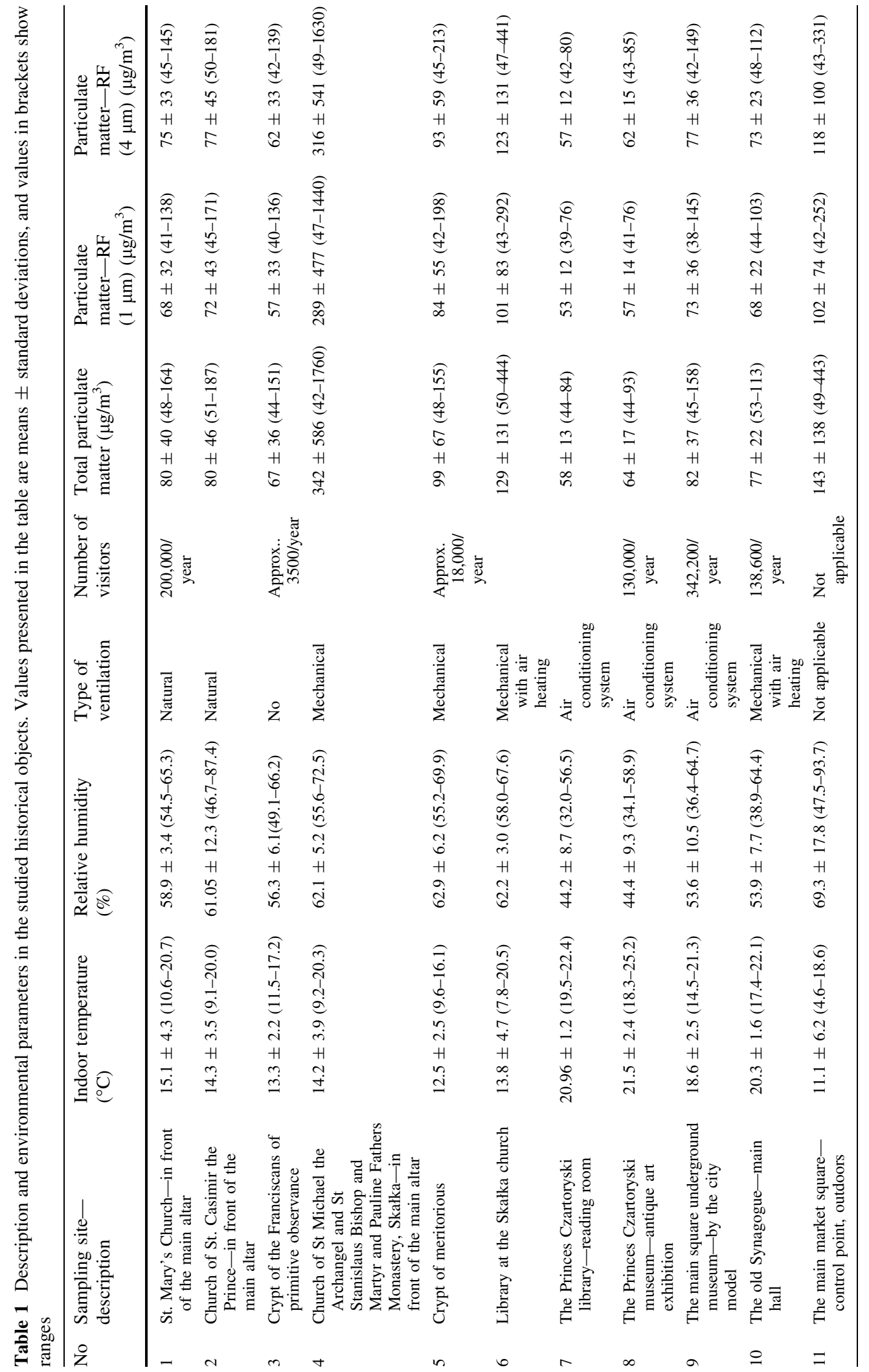


A number of quality control measures were applied in the study. An adequate number of culture media, plates and replicates were used for each series of measurements, following the recommendations of the Polish Standard PN-EN 12322 (s2005). Sterility of the media was ensured by incubating the plates with the media at an appropriate temperature for 3 days (ISO 11133, 2014). Blank plates were used in each series of measurements, and they were incubated at the temperature used for the remaining plates. The measurement devices (Andersen impactor, DustTrak Aerosol Monitor and Kestrel Weather meter), as well as all laboratory equipment used in our study, are regularly checked and have current certificates.

Aggregates containing microorganisms with aerodynamic diameters below $4.7 \mu \mathrm{m}$ were treated as the respirable fraction. In the case of dust, it was assumed that the respirable fraction consists of dust particles smaller than $4.0 \mu \mathrm{m}$.

Statistical analysis was performed using the Statistica 13 software (StatSoft, USA). The normality of data distribution was tested using the Shapiro-Wilk test. The distribution of total bacteria fraction and most environmental parameters was close to normal, while other data were not normally distributed; therefore, both parametric (one-way ANOVA, followed by post hoc Tukey's test) and nonparametric (Kruskal-Wallis test) tests were applied to assess the significance of differences between the concentrations of microbial aerosol in various sites and groups of sites. Spearman's and Pearson's correlation coefficients were applied to assess whether there are statistically significant relations between the concentrations of microbial aerosol components and microclimatic parameters of air in the tested sites.

\section{Results}

The concentrations of both total and respirable fractions of bacterial and fungal aerosols, as well as the concentrations of total and respirable fractions of particulate matter, varied considerably between the tested sites and seasons of the year, as shown in Figs. 1, 2, 3 and 4. For instance, in churches, the mean concentrations of total bacterial aerosol ranged from $35 \mathrm{CFU} / \mathrm{m}^{3}$, recorded in autumn in the Skałka Church (No. 4) to $2890 \mathrm{CFU} / \mathrm{m}^{3}$ in summer in the Church of St. Casimir the Prince (No. 2), and the mean concentrations of fungal aerosol were higher-ranged from $191 \mathrm{CFU} / \mathrm{m}^{3}$ in autumn to $3237 \mathrm{CFU} / \mathrm{m}^{3}$ in summer (both records from the Skałka Church; No. 4). In crypts, the ranges were as follows: $17-420 \mathrm{CFU} / \mathrm{m}^{3}$ for bacteria and $173-1318 \mathrm{CFU} / \mathrm{m}^{3}$ for fungi. In museums, the mean concentrations of bacterial aerosol ranged from $42 \mathrm{CFU} / \mathrm{m}^{3}$ (recorded in autumn in the Princes Czartoryski Museum; No. 8) to $1272 \mathrm{CFU} / \mathrm{m}^{3}$ (Old Synagogue; No. 10; spring), and for fungal aerosol the range was $63 \mathrm{CFU} / \mathrm{m}^{3}$ (winter, Main Square Underground Museum; No. 9)-1742 CFU/m ${ }^{3}$ (summer, Old Synagogue; No. 10). Finally, in the case of libraries the range of mean bacterial aerosol was 53 (autumn, Princes Czartoryski Library; No. 7)-873 (summer, Princes Czartoryski Library; No. 7) CFU/ $\mathrm{m}^{3}$, and for fungal aerosol the range was 109 (autumn, Princes Czartoryski Library; No. 7)-1781 (summer, Skałka Library; No. 6).

The highest concentration, which exceeded the limit value proposed by the ZECB $\left(5360 \mathrm{CFU} / \mathrm{m}^{3}\right)$, was recorded only once-in summer in the Church of St. Casimir the Prince (site No. 2; detailed data, not shown in figures).

Both parametric and nonparametric tests indicated that the differences in bioaerosol concentrations between the tested sites, as well as between groups of sites (churches, crypts, libraries and museums), were not statistically significant $(p>0.05)$. In the case of seasonal changes in the concentrations of microbial aerosol, the differences were statistically significant in the case of all groups of microorganisms $(F=8.40$, $8.65,11.93$ and 10.98 for total bacteria, respirable fraction of bacteria, total concentration of fungi and respirable fraction of fungi, respectively). The number of total and respirable fractions of bacterial bioaerosol differed significantly between summer and autumn and winter, while both total concentrations and respirable fractions of fungal aerosol observed in summer were significantly different from all other seasons $(p<0.05)$. In the case of total and respirable fraction of particulate matter, the values recorded in autumn differed significantly from all other values ( $F=5.25,5.00$ and 5.05 for total dust concentration, $\mathrm{PM}_{1}$ and $\mathrm{PM}_{4}$, respectively).

During sampling, the temperature values indoors ranged from $7.8^{\circ} \mathrm{C}$ at the Library at the Skałka Church (site No. 4) in winter to $25.2^{\circ} \mathrm{C}$ at the Main Square Underground Museum (No. 9) in spring, while the range of relative humidity was within $32.0 \%$ (The 


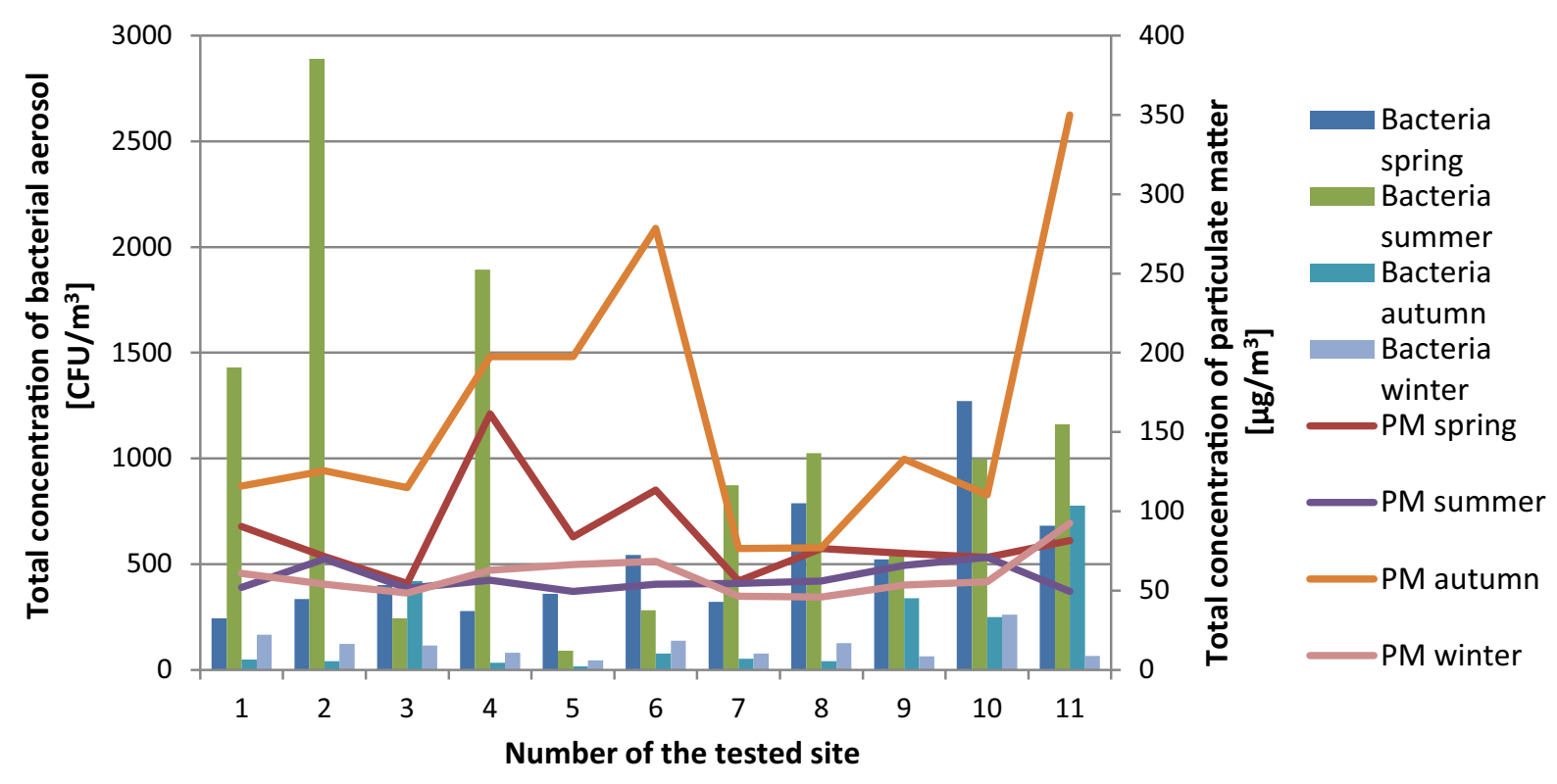

Fig. 1 Concentration of total bacterial aerosol and particulate matter in the examined sites

Princes Czartoryski Library; No. 7) and 69.9\% (Crypt of Meritorious; No. 5) (Table 1).

The mean distributions of aerodynamic diameters of microbial aerosol in the tested groups of historical objects and in the control site are shown in Fig. 5 for bacteria and in Fig. 6 for fungi. In the case of fungi, it is clear that small fractions of bioaerosol dominate in the observed values, as in the case of all groups of objects, the maximum values were recorded for the fraction of $2.1-1.1 \mu \mathrm{m}$. For bacteria, the results are more evenly spread, but still the maximum values were observed for the finest fraction $(1.1-0.65 \mu \mathrm{m})$ in the case of all groups of objects except churches, where the maximum was recorded for the fraction of 3.3-2.1 $\mu \mathrm{m}\left(240 \mathrm{CFU} / \mathrm{m}^{3}\right.$ with the total concentration of $630 \mathrm{CFU} / \mathrm{m}^{3}$ ). However, the differences observed in the case of aerodynamic diameters of both, bacterial and fungal aerosol, were not statistically significant $(p<0.05)$. What also can be noticed is that the differences in the size distribution are very slight between the tested groups of historical objects in the case of fungal aerosol, while in the case of bacteria, these differences are more distinct. Table 2 shows shares of bioaerosol concentrations: total to respirable fraction for both bacteria and fungi and indoor/outdoor ratio for total and respirable fractions of bacterial and fungal aerosols. It also clearly shows that the respirable fraction of bioaerosol prevails, as in most cases the respirable fraction of bacterial aerosol oscillates around $80 \%$ of the total concentration, while in the case of fungal aerosol all results are higher than $80 \%$. Indoor/outdoor ratio was clearly higher for bacteria-in three cases it was $>1$ (1.262 for total bacteria in the Church of St. Casimir the Prince, site No. 2 and in the Old Synagogue museum, site No. 10: 1.034 for total bacteria and 1.212 for respirable fraction).

Positive moderate and statistically significant correlations were found between the concentrations of total and respirable fractions of bacterial aerosol and temperature in spring; in summer-moderate positive correlation between both total and respirable fractions of bacterial aerosol and temperature, PM total concentration, $\mathrm{PM}_{4}$ and $\mathrm{PM}_{1}$; and quite strong negative correlation between the total concentration and respirable fraction of airborne bacteria and relative humidity. For fungal aerosol, there were no statistically significant correlations with environmental parameters (Table 3). 

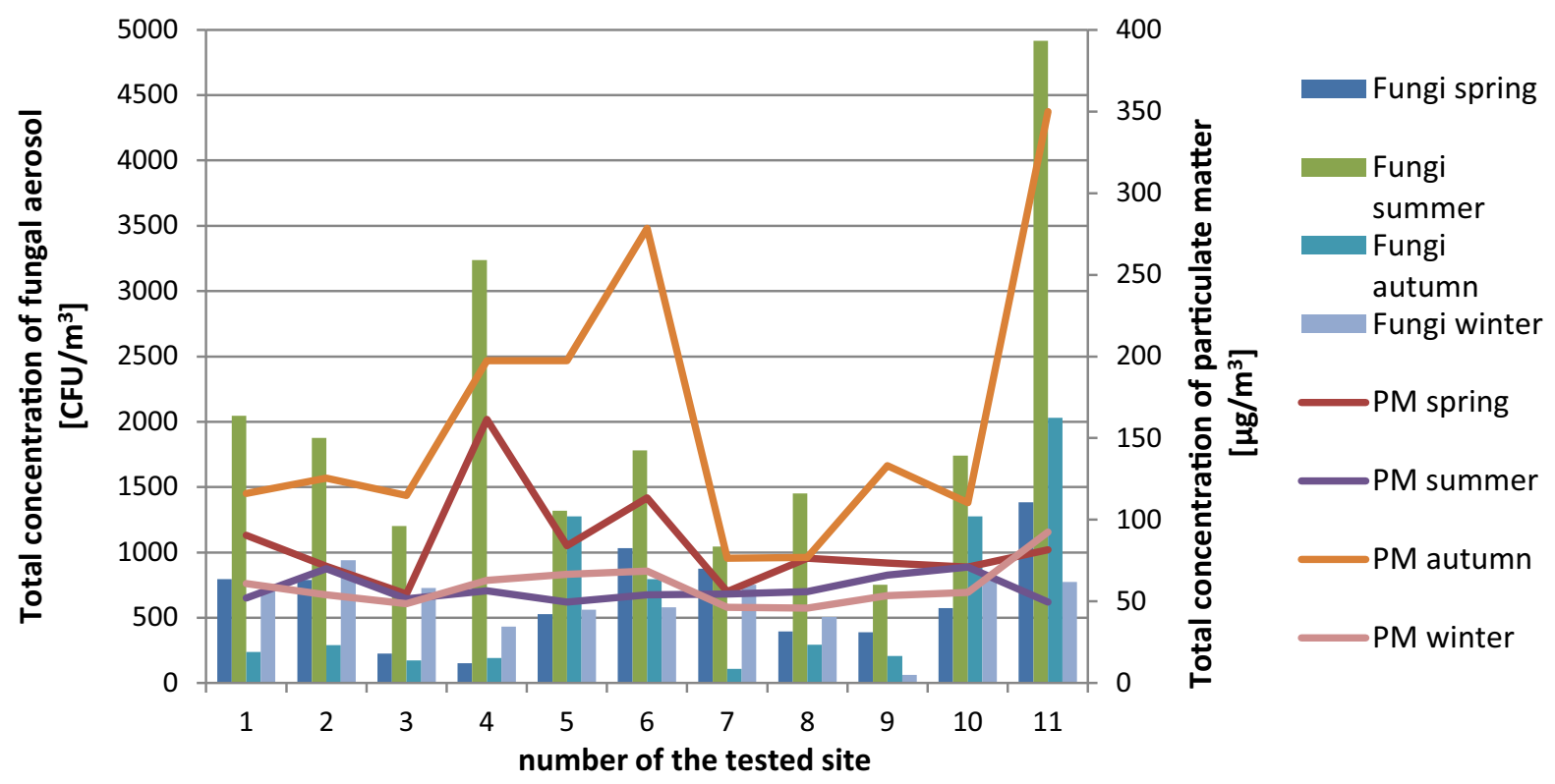

Fig. 2 Concentration of total fungal aerosol and particulate matter in the examined sites

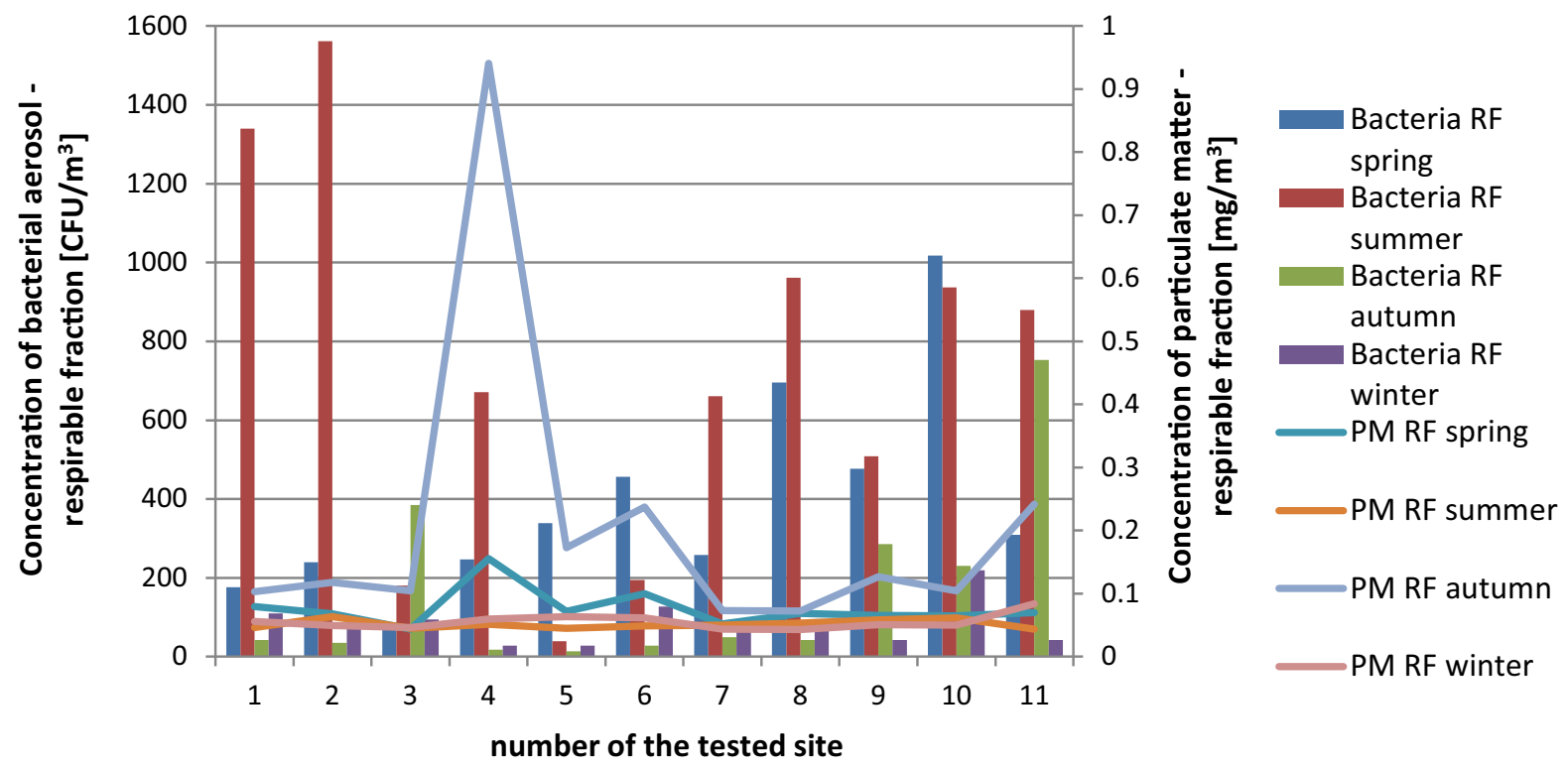

Fig. 3 Concentration of respirable fraction of bacterial aerosol and particulate matter in the examined sites

\section{Discussion}

Although all historical objects examined in this study are also tourist facilities, they differed in terms of their nature of design and utilization, which can determine both the amount and the composition of bioaerosols found there (Karbowska-Berent et al. 2011). The selection of objects for the study allowed to divide them into four categories (churches, crypts, libraries and museums), so that we could try to assess whether 


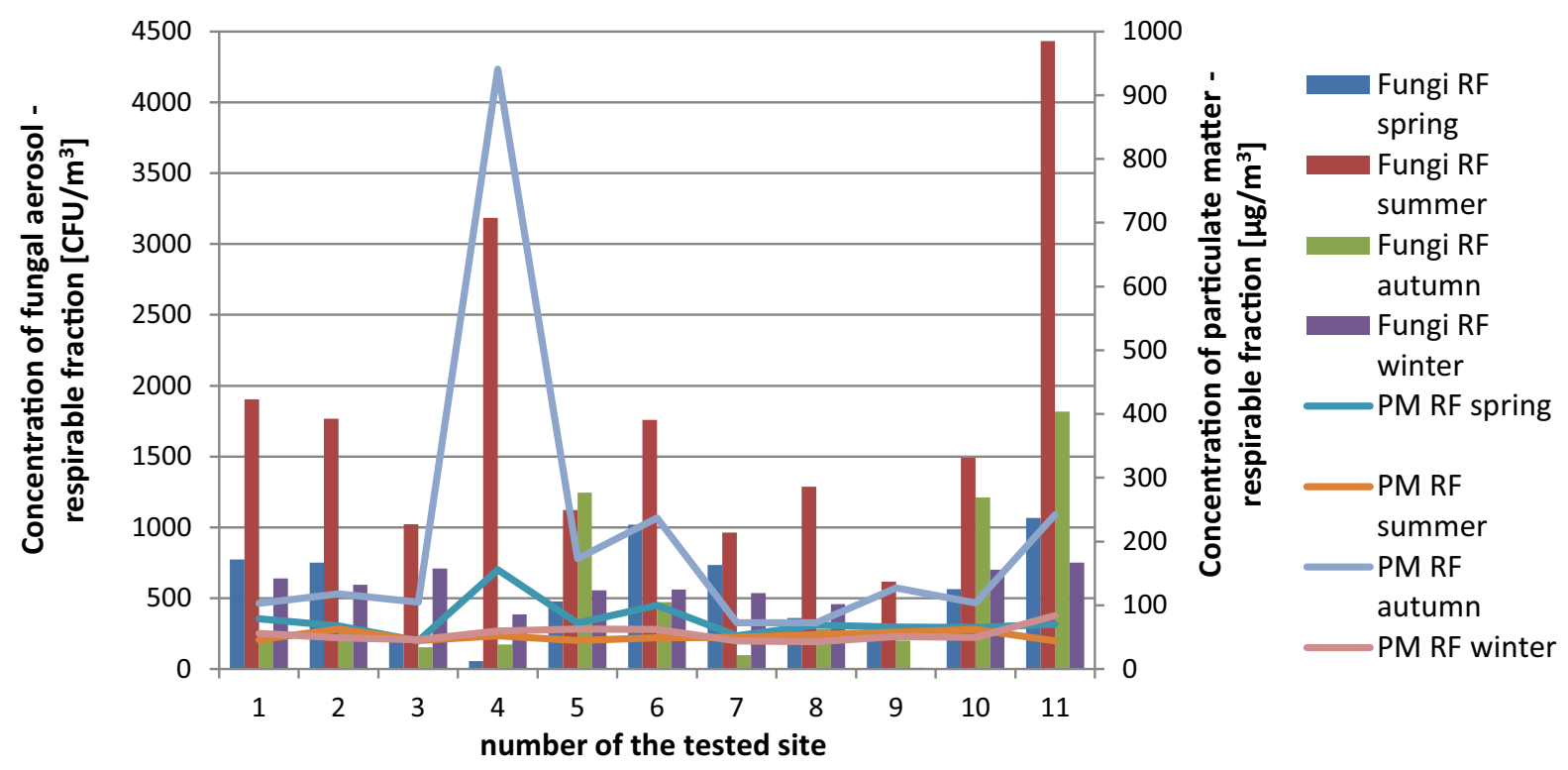

Fig. 4 Concentration of respirable fraction of fungal aerosol and particulate matter in the examined sites

their function actually affected the quality of air. As can be observed in Figs. 1, 2, 3 and 4, the examined sites differed from one another and it cannot be concluded that the concentration of either fungal or bacterial aerosol could allow to cluster them into characteristic groups. The overall assessment of mean numbers of total bacteria and fungi allowed to arrange the tested groups of sites in the following order in terms of bacterial aerosol: churches $>$ libraries $>$ museums $>$ crypts (with mean concentrations of bacterial aerosol ranging from 631 to $212 \mathrm{CFU} / \mathrm{m}^{3}$ of air; $672 \mathrm{CFU} / \mathrm{m}^{3}$ in the outdoor air) and in the case of fungal aerosol: churches $>$ museums $>$ crypts $>$ libraries (from 976 to $706 \mathrm{CFU} / \mathrm{m}^{3} ; 2020 \mathrm{CFU} / \mathrm{m}^{3}$ in the outdoor air). However, the statistical analysis did not reveal any significant differences between individual sites or their groups. It should be mentioned that the examined premises also differed in terms of types and condition of the objects stored, as well as the popularity among tourists, which could significantly affect the quantity of bioaerosol-forming microorganisms (Skóra et al. 2015; Karbowska-Berent et al. 2011). Even though the number of tourists was available in some sites only (Table 1), such relation could be expected, as for instance the St. Mary's Church (site No. 1) is one of the most recognized and most popular tourist places in the entire Kraków, while in the case of crypts the number of tourists is much smaller (particularly in the site No. 3, where the number of visitors is limited to the maximum of c.a. 15 per day, due to the specific nature of the stored objects, i.e., mummies which are very sensitive to the changes in the temperature and humidity).

Except for one observation recorded in summer in the Church of St. Casimir the Prince (site No. 2), the concentrations of fungal or bacterial aerosol did not exceed the acceptable limit of $5000 \mathrm{CFU} / \mathrm{m}^{3}$ which was set for occupational exposure of people working in museums and related institutions suggested by the Expert Group on Biological Agents at the Polish Interdepartmental Commission for Maximum Admissible Concentrations and Intensities for Agents Harmful to Health in the Working Environment (Skowron 2014). Such an increase in bacterial contamination may be related to the numerously frequented Holy Mass, held before the analysis, with the prayer for healing and release, which every day gathers in the church hundreds of people, who are one of the main sources of microbial contamination of indoor air. However, on the same day in the evening there was a significant (more than ten times lower) decrease in the bacterial bioaerosol concentration, which indicates the self-purifying ability of air; therefore, this value should not be treated as disturbing. On the other hand, the limit value of $150 \mathrm{CFU} / \mathrm{m}^{3}$, which can suggest the presence of internal source of contamination which 


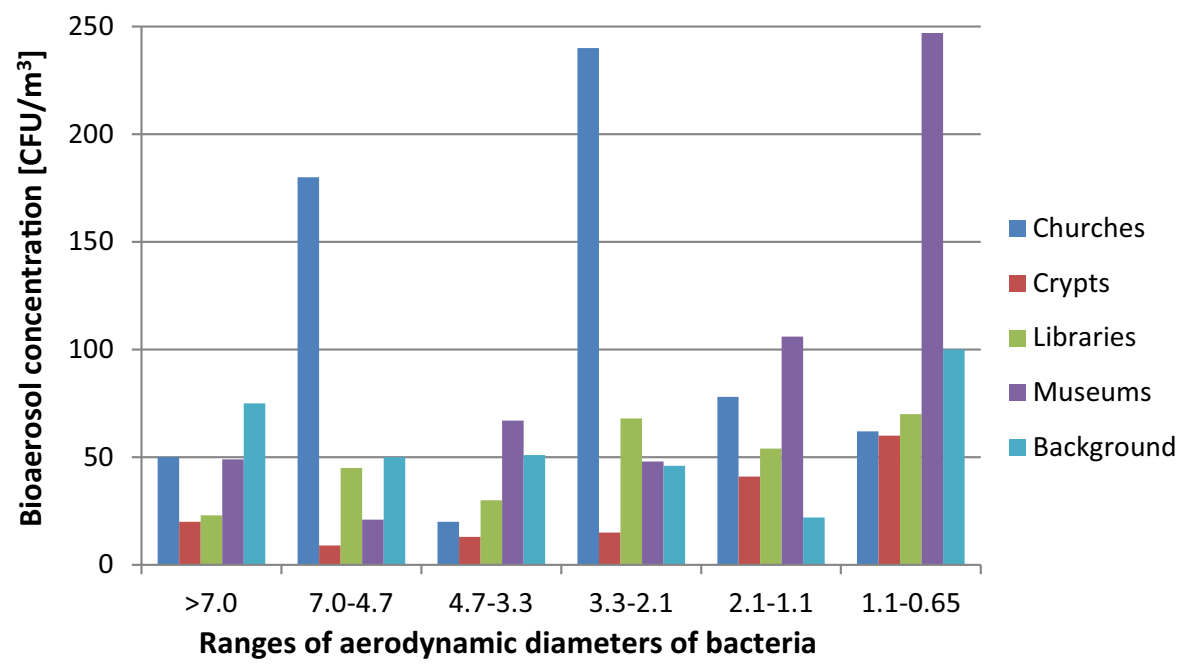

Fig. 5 Concentration of bacterial aerosol within different ranges of aerodynamic diameters in various groups of the examined sites

Fig. 6 Concentration of fungal aerosol within different ranges of aerodynamic diameters in various groups of the examined sites

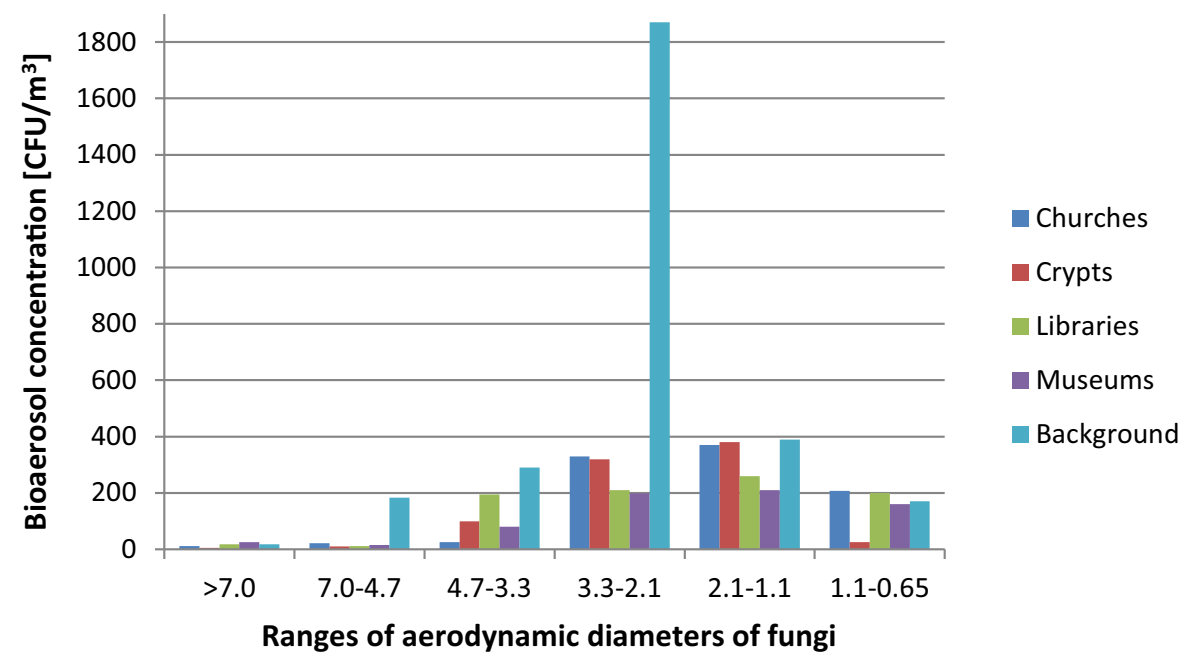

objects, paintings and sculptures, as the limit value of $150 \mathrm{CFU} / \mathrm{m}^{3}$ of air was exceeded in each of the examined churches, in spring and in summer.

As there are not many similar studies conducted in places such as churches and crypts, it is difficult to assess whether the concentrations of bioaerosol observed in our study are typical. For instance, Mashat (2015) observed that the concentrations of bacterial and fungal aerosol in a holy mosque ranged from $10^{2}$ to $10^{5} \mathrm{CFU} / \mathrm{m}^{3}$, while Falkiewicz-Dulik et al. (2016) observed much lower concentrations of bacterial and fungal aerosols - 455 to $1184 \mathrm{CFU} / \mathrm{m}^{3}$ (bacteria) and 124-500 CFU/m $\mathrm{m}^{3}$ (fungi). 
Table 2 Shares of total/respirable fraction and indoor/outdoor for microbial aerosol observed in individual and groups of sites

\begin{tabular}{|c|c|c|c|c|c|c|}
\hline \multirow[t]{2}{*}{ Site no. } & \multirow{2}{*}{$\begin{array}{l}\text { Bacteria total/RF [\% share } \\
\text { T/RF] }\end{array}$} & \multirow{2}{*}{$\begin{array}{l}\text { Fungi total/RF [\% share } \\
\text { T/RF] }\end{array}$} & \multicolumn{4}{|c|}{ Indoor/outdoor (\%) } \\
\hline & & & $\begin{array}{l}\text { Bacteria } \\
\text { total }\end{array}$ & $\begin{array}{l}\text { Bacteria } \\
\mathrm{RF}\end{array}$ & $\begin{array}{l}\text { Fungi } \\
\text { total }\end{array}$ & $\begin{array}{l}\text { Fungi } \\
\text { RF }\end{array}$ \\
\hline $1(\mathrm{Ch})$ & $473 / 417$ [88.2] & $951 / 882[92.7]$ & 0.703 & 0.841 & 0.418 & 0.438 \\
\hline $2(\mathrm{Ch})$ & $848 / 482$ [56.8] & $974 / 845[86.8]$ & 1.262 & 0.972 & 0.428 & 0.419 \\
\hline $4(\mathrm{Ch})$ & $572 / 241[42.1]$ & $1003 / 950$ [94.7] & 0.851 & 0.486 & 0.441 & 0.471 \\
\hline $\begin{array}{l}\text { Churches- } \\
\text { mean }\end{array}$ & $631 / 380[60]$ & 976/892 [91] & 0.939 & 0.766 & 0.429 & 0.442 \\
\hline $3(\mathrm{Cr})$ & $296 / 186[62.8]$ & $582 / 524[90.0]$ & 0.440 & 0.375 & 0.256 & 0.260 \\
\hline $5(\mathrm{Cr})$ & $129 / 105[81.4]$ & $920 / 850[92.4]$ & 0.192 & 0.212 & 0.404 & 0.422 \\
\hline Crypts-mean & 212/146 [69] & $751 / 687$ [91] & 0.315 & 0.294 & 0.330 & 0.341 \\
\hline $6(\mathrm{~L})$ & $261 / 201[77,0]$ & $1047 / 953$ [91.0] & 0.388 & 0.405 & 0.460 & 0.473 \\
\hline $7(\mathrm{~L})$ & $331 / 258$ [77.9] & 696/584 [83.9] & 0.493 & 0.520 & 0.306 & 0.290 \\
\hline $\begin{array}{l}\text { Libraries- } \\
\text { mean }\end{array}$ & 296/230 [78] & $871 / 796$ [91] & 0.440 & 0.464 & 0.383 & 0.395 \\
\hline $8(\mathrm{M})$ & $496 / 449$ [90.5] & $662 / 597[90.2]$ & 0.740 & 0.905 & 0.291 & 0.296 \\
\hline $9(\mathrm{M})$ & $368 / 328[89.1]$ & $353 / 285[80.7]$ & 0.548 & 0.575 & 0.155 & 0.141 \\
\hline $10(\mathrm{M})$ & 695/601 [86.5] & $1101 / 992$ [90.1] & 1.034 & 1.212 & 0.484 & 0.492 \\
\hline $\begin{array}{l}\text { Museums- } \\
\text { mean }\end{array}$ & $520 / 459[88]$ & $706 / 625[89$ & 0.774 & 0.925 & 0.311 & 0.310 \\
\hline Outdoors & $672 / 496[73.8]$ & $2276 / 2016$ [88.6] & - & - & - & - \\
\hline
\end{tabular}

Bolded values show sites where I/O ratio $(>1)$ suggests the presence of an internal source of microorganism emission

For museums, the levels of bioaerosol differed quite clearly between the examined objects. Among museums, the highest bioaerosol concentrations were observed in the Old Synagogue (No. 10), where the limit value suggesting the presence of internal source of air contamination was exceeded in all seasons of the year. This suggests that it would be advisable to carry out procedures aimed at decreasing the number of microorganisms, including humidity reduction or chemical treatments. The concentrations of most of the microbial fractions were the lowest in the Main Square Underground Museum (site No. 9), especially in autumn and in winter. This might be the result of antimicrobial treatments carried out throughout the facility in autumn 2015; therefore, the analysis of indoor air of public utility premises may also provide information on the effectiveness of the applied methods of disinfection. The obtained results allow to conclude that such activities aimed to protect the monuments against biodeterioration should also be applied more than once per year. The mean concentrations of bacterial and fungal aerosol observed in museums are lower than those observed by Skóra et al. (2015), who observed microbial aerosol concentrations within the range of $210-7000 \mathrm{CFU} / \mathrm{m}^{3}$, but on the other hand higher than those observed by LenartBoron et al. (2016) in the premises of the Jagiellonian University Museum (bacterial aerosol range of 0-210 CFU $/ \mathrm{m}^{3}$ and fungal aerosol-50 to $1250 \mathrm{CFU} / \mathrm{m}^{3}$ ) and higher than the levels of fungal aerosol observed by Szostak-Kot et al. (2007) in the Wawel Royal Castle (3-617 CFU/m ${ }^{3}$ ). Niesler et al. (2010) in their study on Auschwitz storerooms observed the bacterial aerosol levels within 126-883 CFU/m $\mathrm{m}^{3}$, but the maximum concentration of fungal aerosol was $49 \mathrm{CFU} / \mathrm{m}^{3}$. Such low concentrations of microbial aerosol observed in the premises of the Auschwitz museum are due to the fact that they are not open to the public. This confirms that in many cases the elevated concentrations of microbial aerosol result from high numbers of people staying and visiting the examined rooms (Karbowska-Berent et al. 2011). Also, Szostak-Kot et al. (2007), who observed similar seasonal fluctuations of bioaerosol 


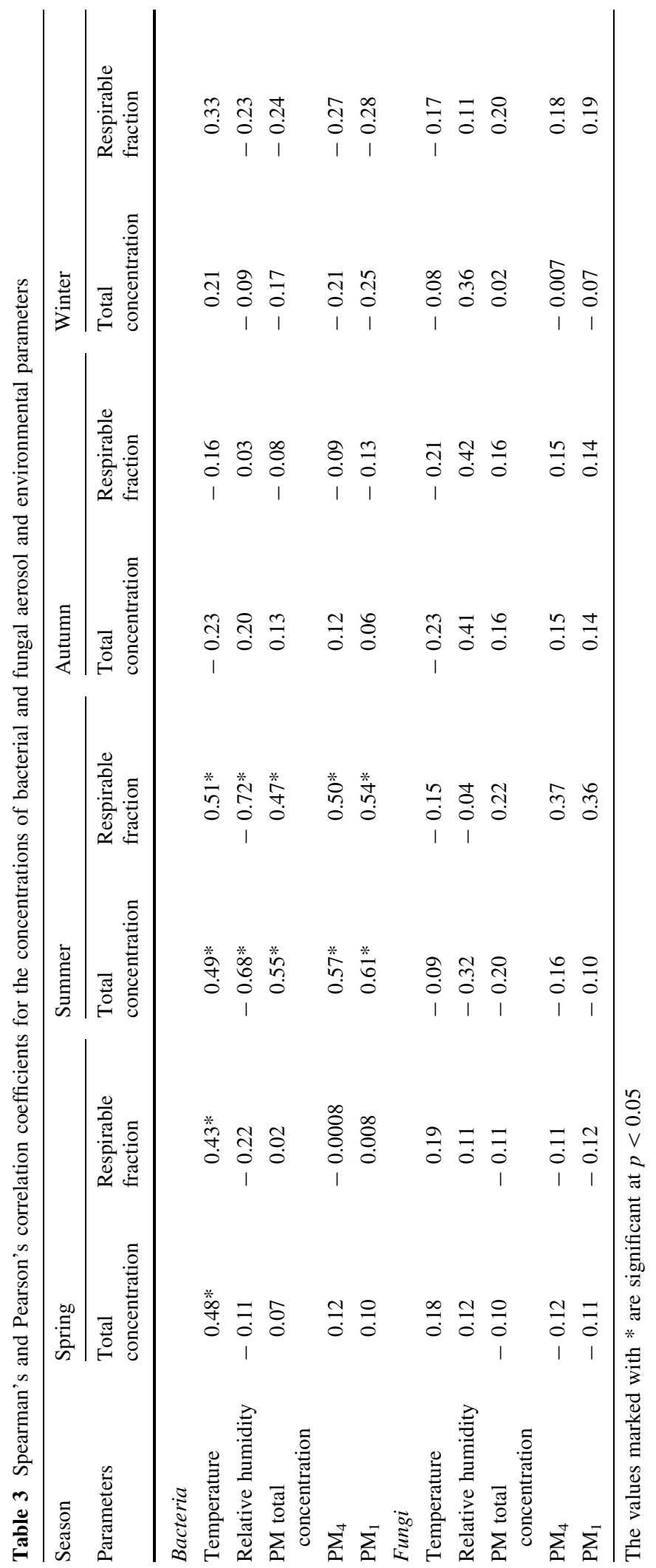


levels as those observed in our study and the highest concentrations of fungal aerosol in summer, concluded that this might be the effect of the highest numbers of tourists visiting the museum premises. In the case of increased concentrations of fungal aerosol, Szostak-Kot et al. (2007) suggest to apply the following preventive measures:

- Continuous monitoring of microclimatic parameters of the studied premises, i.e., temperature and relative humidity;

- Treatments aimed at stabilizing those conditions in summer and/or winter, as well as reducing the humidity to $50 \%$;

- Shaping the intensity of touristic movement and the impact of visitors on the quality of air by, for example, taking into consideration reducing the number of visitors in summer and in winter by introducing the obligation to leave the outwear in the cloakrooms.

In the case of crypts, the concentration of microbial aerosol remained at similar, but low, level. The Crypt of the Franciscans of Primitive Observance (site No. 3) seems to be more exposed to the effects of biodeterioration processes, because of the naturally mummified bodies preserved there. It would be worth to apply antimicrobial treatments that are specifically selected for this type of facility and to install more moisture absorbers. The entrance to the Crypt of the Meritorious (site No. 5) is more often open, allowing for better exchange of air; therefore, the concentration of bacterial aerosol is at very low levels. Also, the material from which the sarcophagi (stone) are made is more difficult to undergo biocorrosion than other types of materials (e.g., wood). There was a significant increase in bacterial and fungal contamination during the spring and summer, when the conditions for the growth of microorganisms were very favorable, particularly higher temperature. Similarly as for churches, literature information on the concentrations of microbial aerosol in crypts is very scarce. The ranges recorded in our study are much lower than the concentration of fungal aerosol observed by Ruga et al. (2015) in the Crypt of St. Peter in Perugia (323-3908 CFU $/ \mathrm{m}^{3}$ in the internal part of the crypt).

Among the analyzed libraries, the one at the Skałka Church (No. 6) seems to be threatened by the fungal biodeterioration, as in summer the concentration of fungal aerosol exceeded $1700 \mathrm{CFU} / \mathrm{m}^{3}$ of air and the minimum concentration observed in winter was nearly $600 \mathrm{CFU} / \mathrm{m}^{3}$. For the Princes Czartoryski Library (No. 7), the levels of fungal aerosol were, however, smaller. When compared to other studies, one can notice that the concentration of microbial aerosol can vary considerably in different libraries, depending on their age, type of stored documents and availability to visitors. Skóra et al. (2015) observed the concentrations ranging from 490 to $5600 \mathrm{CFU} / \mathrm{m}^{3}$, but on the other hand very low levels of microbial aerosol were observed in the library at the Jasna Góra Monastery, where bacterial aerosol levels ranged within 282-862 CFU $/ \mathrm{m}^{3}$ and fungal aerosol reached the maximum of $63 \mathrm{CFU} / \mathrm{m}^{3}$ (Harkawy et al. 2011). However, what should be remembered is that this library is not open to the public and it has a very restricted personnel access. Another important observation in the studies by Harkawy et al. (2011) is that the culturable microorganisms constituted only from 0.5 to $3.9 \%$ of the total microflora, which indicates the shortcomings of the culture-based methods of bioaerosol assessment. Also, Niesler et al. (2010) observed that only a small percentage of microorganisms can be cultured by standard techniques; therefore, culturebased monitoring may underestimate the total exposure to bioaerosols. This is why the studies of hygienic quality of public premises should be supplemented by the techniques allowing also to identify non-culturable microorganisms.

It is considered that the majority of fungal spores are located outdoors, so they might enter most of the examined premises with the outdoor air or on people's clothes. On the other hand, the major indoor reservoirs of bacterial aerosol are considered to be the skin of humans and animals. Therefore, the predominant microorganisms in the atmospheric air would be fungi, while bacteria would prevail indoors (Cox and Wathers 1995; Karbowska-Berent et al. 2011). When the infiltration of outdoor air is excluded, the increased number of fungal particles in the air of libraries, archives and museums may result from the dispersal from some internal sources, e.g., contaminated collections, wallpaper or paint (Karbowska-Berent et al. 2011). In all of the examined groups of historical objects, fungal aerosol outnumbered bacterial aerosol (Table 2). This is important, as contact with airborne fungi, especially for more susceptible individuals, may result in the development of mycoses, as well as allergy-mediated diseases or mycotoxicoses (de Hoog 
1996; Karbowska-Berent et al. 2007). However, one of the most important aspects in the case of potential health effects of microbial, particularly fungal, bioaerosol is its qualitative composition. This shows that most of the quantitative assessments of bioaerosols should be accompanied by qualitative analyses to provide better insight into the actual health implications of bioaerosol exposure, which is unfortunately a drawback of our study, as we only have information about the quantity of bacterial and fungal particles present in the air of the studied historical objects.

Another way of assessing the level of contamination of indoor air is the indoor/outdoor ratio (Górny et al. 2016). If the $\mathrm{I} / \mathrm{O}$ ratio is $<1$, it is usually interpreted that indoor air of a given facility is not contaminated, or its level is acceptable. According to American Industrial Hygiene Association (1989) or Reynolds et al. (1990), if the I/O is $>1$, it suggests the presence of an internal source of microorganism emission. Obviously, the greater the value, the more likely it is (Reynolds et al. 1990). In our study, such a situation was observed only in two sites and only in the case of bacterial aerosol (Church of St. Casimir the Prince [site No. 2] and the Old Synagogue Museum [site No. 10]). However, what should be noted is that the concentrations of fungal aerosol recorded outdoors were quite high, with a significantly large share of the respirable fraction of fungal aerosol in the case of outdoor air. Also, it seems that the type of ventilation does not affect significantly the $\mathrm{I} / \mathrm{O}$ ratio observed in our study. The two sites, where the I/O ratio exceeded 1 differed in terms of the ventilation type, i.e., site No. 2 had natural ventilation, while No. 10-mechanical with air heating. Also, the only site with no ventilation at all (No. 3) was characterized by relatively low values of the observed parameters, but on the other hand, similarly low levels of bacterial and fungal aerosol were recorded in the site No. 9, where there is an air conditioning system. The incongruence of the observations indicates that it would be necessary to conduct a more detailed study, including qualitative assessment of bioaerosol composition, as well as the concentration and species composition of microorganisms present in the settled dust (Górny et al. 2016).

By using a six-stage Andersen impactor, we were able to analyze the size distribution of bioaerosol particles at the studied places. Most importantly, it allowed to determine the share of respirable fraction in the total concentration of bioaerosols. As shown in
Figs. 5 and 6, as well as in Table 2, in all of the examined groups of historical objects, respirable fraction (i.e., particles of diameter less than $4.7 \mu \mathrm{m}$ ) is predominant. Taking into consideration the natural sizes of bacterial and fungi in the air, such analysis can allow to determine the possible depth of bioaerosol penetration into the human respiratory system (Górny et al. 2016). According to many studies, particles smaller than $2.5 \mu \mathrm{m}$ pose the greatest hazard to the health of people exposed, as they can penetrate deeply into the respiratory tract (e.g., pulmonary alveoli), resulting in numerous, even severe health outcomes ranging from low birth weight, through pulmonary and cardiovascular diseases to cancer and premature death (Morakinyo et al. 2016).

What also can be observed from the figures showing the distribution of respirable fraction of bioaerosol is that the highest concentrations of respirable fraction are mostly observed in summer. This is more evident in the case of fungi, as only in the Crypt of Meritorious (No. 5) the highest concentrations of fungal RF were observed in autumn, whereas in the case of bacteria this was observed for more than half of the examined sites. These observations are similar to those of Mędrela-Kuder (1999), who in the study conducted in Kraków observed that the number of airborne fungal spores significantly increases in summer, when the particles of Cladosporium and Alternaria, causing allergic symptoms in humans, occur in particularly large numbers. Likewise, Frak et al. (2014) in their study aimed at assessing the number of microorganisms adsorbed on $\mathrm{PM}_{10}$ and demonstrated that fungal particles are more subject to seasonal variation with the highest numbers observed in summer months. Also, the size distribution in different groups of historical objects is more evenly spread for fungi, as the share of a diameter of $2.1-1.1 \mu \mathrm{m}$ was predominant in all groups of the tested sites (Fig. 6), whereas in the case of bacteria the results are much more scattered. Similar observations were shown by Górny et al. (2016) in their study on microbial aerosol concentrations in cultural heritage conservation laboratories. The predominant share of fungal and bacterial aerosol was slightly higher $(2.1-3.3 \mu \mathrm{m})$, but the aerodynamic diameter sizes are also more evenly spread in the case of fungi than for bacteria. Also, Clauß (2015) in a comprehensive review showed that the particle size of fungi is more evenly distributed and that the sizes of 1.0-3.2 $\mu \mathrm{m}$ are predominant. This was 
attributed to the fact that mold spores are occurring as single spores in more than $65 \%$ of cases. Similarly in our study, the share of respirable fraction of bioaerosol was visibly higher in the case of fungi (from 80.7 to $94.7 \%$ of total fraction of fungi and from 42.1 to $90.5 \%$ for bacteria). The observed proportions of respirable fraction of microorganisms are similar to those observed by other authors in similar environments. For instance, Górny et al. 2016 in their study on cultural heritage conservation laboratories also observed that fractions below $3.3 \mu \mathrm{m}$ had the greatest proportion, while Braggoszewska et al. (2018) in their study conducted in schools reported the concentration of bacterial RF from 73 to $84 \%$. However, there are also reports showing that the share of RF ranges from 30 to $60 \%$ (e.g., Skóra et al. 2015; Kim and Kim 2007), and as indicated by Braggoszewska et al. (2018), the percentage of RF exceeding $80 \%$ should be treated as the one posing serious health risks.

Moreover, as shown by Clauß (2015), large differences can be observed between different environments, and the fact that, for example, in public buildings the particles of 1.1-2.1 $\mu \mathrm{m}$ are predominant might result from the lack of multiple sources of airborne microorganisms, easy to clean surfaces and effective air cleaning systems. What is also interesting is that there may be considerable differences in the size distributions of particles carrying microorganisms within a type of environment and even within a particular facility. As shown in Table 2, in churches the share of respirable fraction of bacterial aerosol in our study ranged from 42.1 in the Skałka Church (No. 4) to more than twice a higher proportion of $88.2 \%$ in St Mary's Church (No. 1). These changes may be due to various reasons, among which relative humidity is mentioned as the predominant factor by numerous authors (Clauß 2015). In the case of our study, microclimatic parameters such as temperature and RH were similar in all three churches and the concentration of particulate matter, both total and RF, was much higher in the St Mary's Church (No. 1). Perhaps, in this case the concentration of $\mathrm{PM}_{4}$ and $\mathrm{PM}_{1}$ might be the factor affecting the concentration of bacterial aerosol. This is supported by the correlation coefficients shown in Table 3, as in summer we observed moderate positive correlation between the concentration of bacterial aerosol and PM concentration.
However, the relationships between the concentrations of PM and microbial aerosol (Table 3 and Figs. 1, 2, 3 and 4) show that there are no obvious dependencies in our research. Only in the case of bacterial aerosol, the correlation coefficients were statistically significant. No statistically significant relationships were observed for fungi. These observations differ from the ones by, for example, Frak et al. (2014), who concluded that a large share of microorganisms spread in atmospheric air with suspended particulate matter $\mathrm{PM}_{10}$, and fungi are the predominant group spread with $\mathrm{PM}_{10}$. Also, Skóra et al. (2015) observed significant correlations between the dust levels and the air contamination with microorganisms (with correlation coefficients ranging from 0.794 to $0.908, p>0.05)$. Our findings might result from the fact that - as can be seen from Figs. 1, 2, 3 and 4-the concentration of respirable fraction of particulate matter did not vary considerably between the examined sites and in different seasons of the year. Only in autumn, there were very high concentrations of $\mathrm{PM}_{4}$ and $\mathrm{PM}_{1}$ observed in the Skałka Church (No. 4). The concentrations of total PM were more varied between particular sites, but also the differences were not statistically significant.

\section{Conclusions}

Since the air is a very good transport medium for ubiquitous microorganisms, the analyses of its microbial quality in historic buildings are important because of the need to obtain the best knowledge about the possible risks-both health risks to tourists, visitors and employees and the risks related to the deterioration of the stored objects. If no action is taken and historical objects are left to environmental factors and are inadequately protected, they would deteriorate irretrievably.

Our study showed that the concentrations of airborne bacteria and fungi differed between the examined groups of sites as well as between individual sites, but these differences were not statistically significant. This could be related to the fact that the studied places also differ between one another in terms of the availability to visitors, types and condition of the stored objects, as well as in terms of microclimatic parameters, among which temperature seemed to have the greatest impact on their prevalence. However, 
contrary to observations of many other researchers, our study did not show any clear relationship between the concentration of dust particles and microbial aerosol.

The observed concentrations of bioaerosol did not exceed the acceptable limits for human exposure, but it did exceed the levels indicating the possible threat of biodeterioration of the stored objects and suggesting the presence of internal sources of contamination. This indicates the need to apply some preventive measures and treatment procedures that would allow to mitigate the microbial contamination of air in the examined premises. This is even more important, as we observed that the concentrations of fungal aerosol outnumbered bacterial aerosol and although we did not assess the species composition of airborne fungi, it is commonly known that even if there are no pathogenic fungal strains, many of them can cause allergies or irritations to the respiratory tract. What is also important is that the share of respirable fraction was evidently higher for fungal bioaerosol with the levels reaching almost $95 \%$.

Our observations show that the aerosol within the studied historical objects may penetrate the human respiratory system. This can happen through nasal and oral cavities, primary, secondary and terminal bronchi and the pulmonary bronchioles, with solid particles present in dust acting as carriers. This may cause irritation of the mucous membranes of the nose and eyes, and an inflammatory response or allergic reactions in exposed people.

Acknowledgements This study was funded by the statutory measures of the University of Agriculture-Grant No. DS 3159/KM.

Open Access This article is distributed under the terms of the Creative Commons Attribution 4.0 International License (http:// creativecommons.org/licenses/by/4.0/), which permits unrestricted use, distribution, and reproduction in any medium, provided you give appropriate credit to the original author(s) and the source, provide a link to the Creative Commons license, and indicate if changes were made.

\section{References}

American Industrial Hygiene Association. (1989). The practitioner's approach to IAQ investigations. In D. M. Weekes, R. B. Gammage (Eds.), Proceedings of the indoor air quality international symposium (pp. 43-66). St. Louis, USA: Fairfax.

Aydogdu, H., Asan, A., \& Otkun, M. T. (2010). Indoor and outdoor airborne bacteria in child day-care centers in Edirne City (Turkey), seasonal distribution and influence of meteorological factors. Environmental Monitoring and Assessment, 164(1-4), 53-66.

Brągoszewska, E., \& Biedroń, I. (2018). Indoor air quality and potential health risk impacts of exposure to antibiotic resistant bacteria in an office rooms in southern Poland. Atmosphere. https://doi.org/10.3390/ijerph15112604.

Brągoszewska, E., Mainka, A., \& Pastuszka, J. S. (2016). Bacterial and fungal aerosols in rural nursery schools in southern Poland. Atmosphere. https://doi.org/10.3390/ atmos7110142.

Brągoszewska, E., Mainka, A., Pastuszka, J. S., Lizończyk, K., \& Desta, Y. G. (2018). Assessment of bacterial aerosol in a preschool, primary school and high school in Poland. Atmosphere. https://doi.org/10.3390/atmos9030087.

Brągoszewska, E., \& Pastuszka, J. S. (2018). Influence of meteorological factors on the level and characteristics of culturable bacteria in the air in Gliwice, Upper Silesia (Poland). Aerobiologia, 34, 241-255.

Clauß, M. (2015). Particle size distribution of airborne microorganisms in the environment-A review. Landbauforschung Volkenrode, 65(2), 77-100. https://doi.org/ 10.3220/LBF1444216736000.

Cox, C. S., \& Wathers, C. M. (1995). Bioaerosols handbook. Boca Raton: Lewis Publishers/CRC Press Inc.

de Hoog, G. S. (1996). Risk assessment of fungi reported from humans and animals. Mycoses, 39, 401-417.

Dong, L., Qi, J., Shao, C., Zhong, X., Gao, D., Cao, W., et al. (2016). Concentration and size distribution of total airborne microbes in hazy and foggy weather. Science of the Total Environment, 541, 1011-1018.

Falkiewicz-Dulik, M., Bulski, K., Ostafin, M., Czuszkiewicz, J. \& Kurek, T. (2016). The assessment of exposure to bacterial and fungal aerosol in the St. Benedict Church in Cracow. In International conference of biodeterioration and protection of cultural heritage, (pp. 22-23).

Frąk, M., Majewski, G., \& Zawistowska, K. (2014). Analysis of the quantity of microorganisms adsorbed on particulate matter PM10. Scientific Review-Engineering and Environmental Sciences, 64, 140-149.

Górny, R. L., Harkawy, A. S., Ławniczek-Wałczyk, A., Karbowska-Berent, J., Wlazło, A., Niesler, A., et al. (2016). Exposure to culturable and total microbiota in cultural heritage conservation laboratories. International Journal of Occupational Medicine and Environmental Health, 29(2), 255-275.

Harkawy, A., Górny, R. L., Ogierman, L., Wlazło, A., Ławniczek-Wałczyk, A., \& Niesler, A. (2011). Bioaerosol assessment in naturally ventilated historical library building with restricted personnel access. Annals of Agricultural and Environmental Medicine, 18(2), 323-329.

ISO 11133:2014. (2014). Microbiology of food, animal feed and water-Preparation, production, storage and performance testing of culture media.

Karbowska-Berent, J., Górny, R. L., Strzelczyk, A. B., \& Wlazło, A. (2011). Airborne and dust borne 
microorganisms in selected Polish libraries and archives. Building and Environment, 46, 1872-1879.

Karbowska-Berent, J., Jarosińska, D., \& Muszyńska-Graca, M. (2007). Ocena stopnia narażenia pracowników bibliotek i archiwów na alergie i grzybice w środowisku pracy. Notes Konserwatorski, 11, 255-266.

Kim, K. Y., \& Kim, C. N. (2007). Airborne microbiological characteristics in public buildings of Korea. Building and Environment, 42, 2188-2196.

Lenart-Boroń, A., Więckowska, M., \& Pollesch, J. (2016). Microbiological contamination in the selected premises of the Jagiellonian University Museum. Opuscula Musealia, 24, 151-158.

Liu, X., Zhai, Y., Zhu, Y., Chen, H., Li, P., Peng, C., et al. (2015). Mass concentration and health risk assessment of heavy metals in size-segregated airborne particulate matter in Changsha. Science of the Total Environment, 517, 215-221.

Mashat, B. (2015). Indoor and outdoor microbial aerosols at the holy mosque: a case study. Atmospheric Pollution Research, 6(6), 990-996.

Mędrela-Kuder, E. (1999). The occurrence of fungi spores in the atmospheric air in the area of Cracow with regard to dust pollution. Archives of Environmental Protection, 25(1), 63-70.

Morakinyo, O. M., Mokgobu, M. I., Mukhola, M. S., \& Hunter, R. P. (2016). Health outcomes of exposure to biological and chemical components of inhalable and respirable particulate matter. International Journal of Environmental Research and Public Health, 13(6), 592. https://doi.org/10. 3390/ijerph13060592.

Nasir, Z. A., \& Colbeck, I. (2010). Assessment of bacterial and fungal aerosol in different residential settings. Water, Air, and Soil Pollution, 211, 367-377.

Niesler, A., Górny, R. L., Wlazło, A., Łudzeń-Izbińska, B., Ławniczek-Wałczyk, A., Gołofit-Szymczak, M., et al. (2010). Microbial contamination of storerooms at the Auschwitz-Birkenau Museum. Aerobiologia, 26, 25-133.
PN-EN 12322. (2005). In vitro diagnostic medical devices. Culture media for microbiology. Performance criteria for culture media.

Reynolds, S. J., Streifel, A. J., \& McJilton, C. E. (1990). Elevated airborne concentrations of fungi in residential and office environments. American Industrial Hygiene Association Journal, 51, 601-604.

Ruga, L., Orlandi, F., Romano, B., \& Fornaciari, M. (2015). The assessment of fungal bioaerosols in the crypt of St. Peter in Perugia (Italy). International Biodeterioration and Biodegradation, 98, 121-130.

Skóra, J., Gutarowska, B., Pielech-Przybylska, K., Stępień, Ł., Pietrzak, K., Piotrowska, M., et al. (2015). Assessment of microbiological contamination in the work environments of museums, archives and libraries. Aerobiologia, 31, 389-401.

Skóra, J., Zduniak, K., Gutarowska, B., \& Rembisz, D. (2012). Harmful biological agents at museum workposts. Medycyna Pracy, 63(2), 153-165.

Skowron, J. (2014). The activity of the interdepartmental commission for maximum admissible concentrations and intensities for agents harmful to health in the working environment in 2011-2013. Podstawy i Metody Oceny Środowiska Pracy, 1(79), 161-184. (in Polish).

Strzelczyk, A. B. (2004). Observations on aesthetic and structural changes induced in Polish historic objects by microorganisms. International Biodeterioration and Biodegradation, 53(3), 151-156.

Szostak-Kot, J., Syguła-Cholewińska, J., \& Błyskal, B. (2007). Analysis of air microflora in the Wawel Royal Castle exhibition rooms. Polish Journal of Commodity Science, 3(12), 85-99.

Valentin, N. (2003). Microbial contamination and insect infestation in organic materials. Coalition, 6, 2-5.

Wiszniewska, M., Walusiak-Skorupa, J., Pannenko, I., Draniak, M., \& Palczyński, C. (2009). Occupational exposure and sensitization to fungi among museum workers. Occupational Medicine, 59, 237-242. 